Gut, 1963, 4, 261

\title{
Use of labelled triolein, vitamin A, and D-xylose in the diagnosis of malabsorption ${ }^{1}$
}

\author{
K. G. WORMSLEY
}

From Manchester Royal Infirmary

EDITORIAL SYNOPSIS This paper discusses the type of results given by a group of test procedures used in the study of small intestinal dysfunction. While the chemical estimation of faecal fat remains the most valuable criterion for the laboratory detection of malabsorption, the occurrence of abnormal faecal or blood radioactivity also denotes the presence of malabsorption, although some patients with steatorrhoea appear to 'absorb' labelled triolein normally. Analysis of data from the other tests shows that steatorrhoea is not necessarily present in patients who give abnormal results and that the presence of malabsorption does not preclude a normal capacity for handling the test substances. These reservations impair the value of the vitamin A and xylose 'tolerance' tests and serum carotene levels as screening procedures for the determination of malabsorption states. On the other hand, these tests show patterns of results which are useful in differentiating idiopathic from secondary steatorrhoea, since patients with secondary malabsorption often handle one or more of these test substances normally.

The problem of detecting malabsorption, no less than evaluating its severity and determining its aetiology, has demanded the attention of clinicians since the recognition of steatorrhoea by Kuntzman in 1824. Initially, the diagnosis was made by the naked eye and by microscopical study of the stools, techniques which, still valuable, detect only more severe small intestinal dysfunction and fail to indicate the cause of the disease. Subsequent refinements in diagnostic techniques, including definitive radiology of the small intestine (Marshak, Wolf, and Adlersberg, 1954) and more recently biopsy of the small intestine (Shiner, 1959; Crosby and Kugler, 1957), have added to our knowledge, and additional information has been obtained by the use of specific chemical substances to measure the digestive and absorptive capacity of the small intestine. The validity and reliability of some of the individual laboratory techniques in assessing malabsorption have been critically discussed recently by several authors (Pimparkar, Tulsky, Kalser, and Bockus, 1960; Cox, 1961; George and Hennessy, 1961; Rufin, Bland, Nordyke, and Grossman, 1961). Using a variety of chemical procedures an intensive study has been made of a control group and of a group of patients with malabsorption of differing origin, and the results are presented in this paper.

'Part of a thesis submitted to the University of London.
CLINICAL MATERIAL

The one hundred and one patients included in this study are summarized in Table $I$.

TABLE I

SUMMARY OF PATIENTS INVESTIGATED

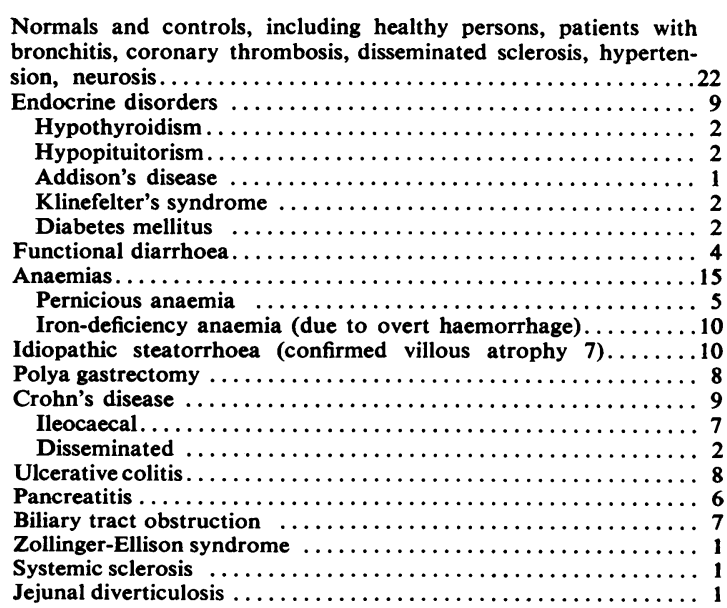

METHODS

Most of the investigations were carried out concurrently 
by standard techniques and a considerable number were repeated.

FAT BALANCES Standard daily diets contained $80 \mathrm{~g}$. of fat. Total faecal lipids were estimated (Harrison, 1957).

${ }^{131}$ IODINE-LABELLED TRIOLEIN Fifteen to $30 \mu \mathrm{c}$. in $300 \mathrm{ml}$. milk was administered 30 minutes after a standard breakfast containing $35 \mathrm{~g}$. fat. Blood levels and faecal excretion were estimated in a scintillation counter and 'ring of six' counter (Veall and Vetter, 1952) respectively, and compared with sodium ${ }^{131}$ iodide standards.

SERUM CAROTENE AND VITAMIN A TOLERANCE TESTS Vitamin A palmitate, 350,000 units, in $5 \mathrm{ml}$. arachis oil was given 30 minutes after breakfast. Vitamin $A$ and carotene were estimated according to Kimble's method as described by Yudkin (1941).

WATER LOAD TEST Water loads ranging from 0.5 to 2.51 . were administered to fasting patients and after food, and urine was collected for five hours subsequently.

D-XYlose eXCretion test Xylose, $25 \mathrm{~g}$., in 0.5 to 2.51 . water was administered to fasting patients and urine was collected for five hours. Urinary xylose was estimated according to the method of Roe and Rice (1948) and urinary creatinine by the method of Bonsnes and Taussky (1945).

\section{RESULTS}

Fat Balances Previous laboratory experience, using the identical technique for several years, gave an upper limit of normal fat excretion of $8 \%$ of intake. (It is appreciated that this terminology does not imply a specific origin for the faecal fat, but permits comparing the results of this study with other reports.) Twenty-nine balances were repeated, in four $(14 \%)$ of which the results showed sufficient qualitative variation to make the state of absorption at that time uncertain. In three of these patients (one after gastrectomy and two with ulcerative colitis) a striking change was noted in bowel motility and may have been responsible for the variation in fat excretion. Fat balance results were compared with analyses of maximum or minimum 24-hour stool collections during the balance period in order to demonstrate the maximum possible divergence of random analyses from fat balance results. Seventeen per cent of 65 results showed disagreement. Five patients had normal fat balance results and abnormal single-day values, and six patients with abnormal fat balances had normal 24-hour results (Table II).

${ }^{131}$ IODINE-LABELLED TRIOLEIN The concurrent use of labelled triolein proved to be a convenient first marker in fat balance procedures. Reproducibility of both faecal losses and blood peak values was excellent, only one patient showing a qualitative change in faecal excretion on repetition of the test. Mean normal faecal excretion was $1.8 \%$ of intake (S.D. \pm 0.7). Using an upper limit of normal faecal loss of $3.2 \%$ (mean +2 S.D.), six patients (17\%) without steatorrhoea had faecal losses greater than this value and $12(28 \%)$ with abnormal fat balance results showed normal faecal radioactivity (Table III). Thus, an overall $23 \%$ of 78 patients showed dis-

\section{TABLE III}

CORRELATION OF FAT BALANCES AND FAECAL LOSSES OF RADIOACTIVE MATERIAL

Fat Balances

\begin{tabular}{|c|c|c|c|c|}
\hline \multirow{3}{*}{ Faecal Radioactivity } & \multirow{2}{*}{\multicolumn{2}{|c|}{ Separate Groups }} & \multirow{2}{*}{\multicolumn{2}{|c|}{ Combined }} \\
\hline & & & & \\
\hline & Normal & Abnormal & Normal & Abnormal \\
\hline \multirow[b]{2}{*}{$\begin{array}{r}\text { Normal }<3.2 \% \\
\text { Normal } \\
\text { Abnormal }\end{array}$} & $(35)^{1}$ & $(43)^{1}$ & \multicolumn{2}{|c|}{$(78)^{1}$} \\
\hline & $\begin{array}{l}83 \% \\
17 \%\end{array}$ & $\begin{array}{l}28 \% \\
72 \%\end{array}$ & $8 \%$ & $15 \%$ \\
\hline $\begin{array}{c}\text { Normal }<5.0 \% \\
\text { Normal } \\
\text { Abnormal }\end{array}$ & & & $1 \%$ & $30 \%$ \\
\hline
\end{tabular}

${ }^{1}$ Number of patients in each group.

cordant results. Using an arbitrary maximum normal faecal loss of $5 \%$, as suggested by Ruffin, Shingleton, Baylin, Hymans, Isley, Sanders, and Sohmer (1956) and by Cox (1961), only one patient, who had chronic pancreatitis but no steatorrhoea, gave a false positive result with abnormal faecal radioactivity, while $54 \%$ of the 43 patients with steatorrhoea showed normal faecal radioactivity. These false negative results were distributed through all the groups (Table IV).

The mean normal value for peak blood radioactivity was $3 \cdot 7 \%$ of intake per litre (S.D. $\pm 1.0 \%$ ) and the mean normal peak total blood radioactivity

TABLE II

RESULTS OF FAT BALANCES

Duplicate Fat Balances

\begin{tabular}{lll}
\hline Both Normal & $\begin{array}{l}\text { One Normal and } \\
\text { One Abnormal }\end{array}$ \\
\hline
\end{tabular}

Fat Balance Compared with Single Day Collections

Both Normal $\quad$ F.B. Normal and Single Both Abnormal
Day Collection Abnormal $5(8 \%)$ 36 
TABLE IV

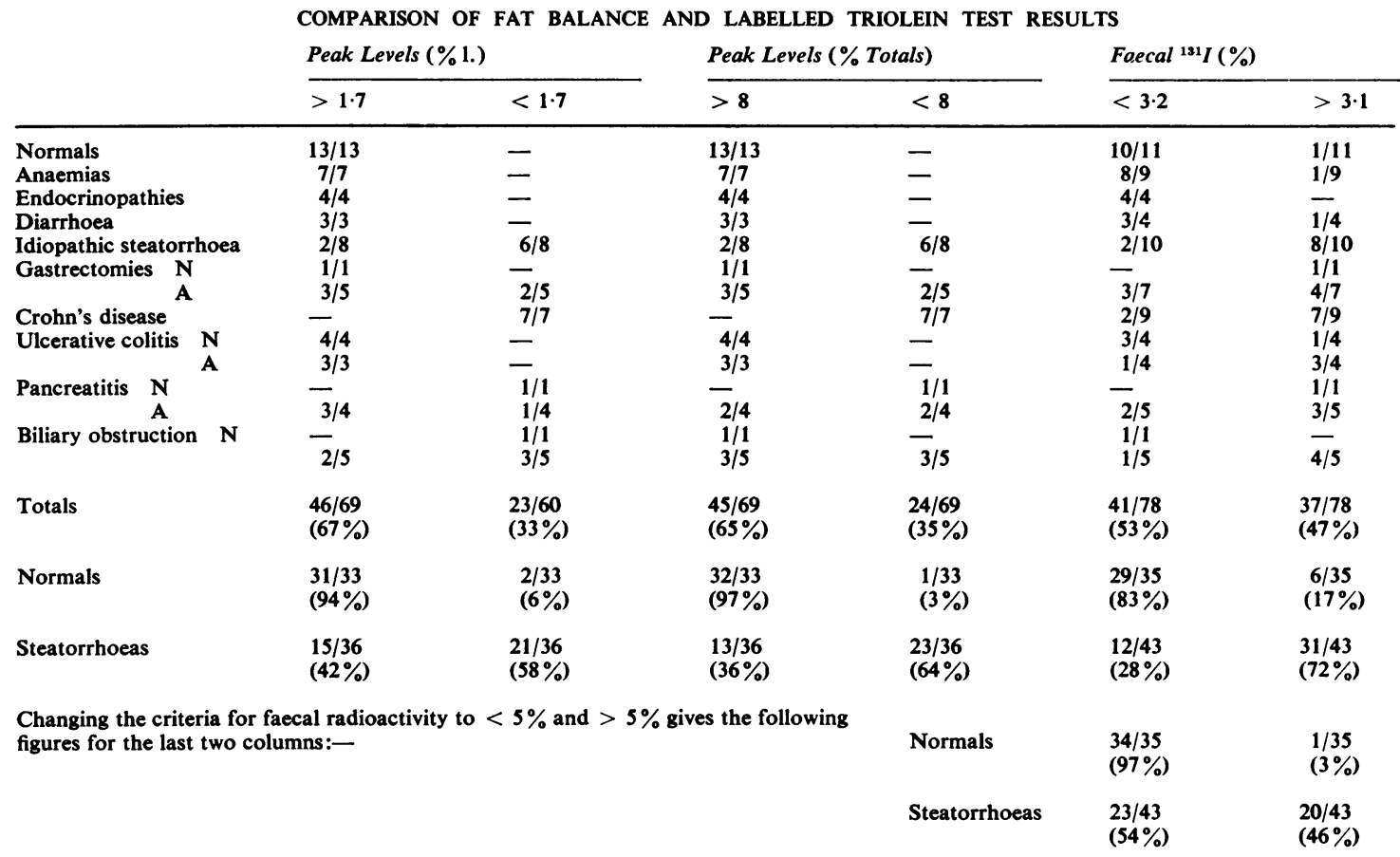

The figures refer to number of patients. $\quad \mathrm{N}$ indicates patients with normal faecal fat and $\mathbf{A}$ those with steatorrhoea.

TABLE V

CORRELATION OF RESULTS OF FAT BALANCES AND OF LABELLED TRIOLEIN TESTS

\begin{tabular}{|c|c|c|c|c|c|}
\hline & & \multicolumn{4}{|c|}{ Fat Balances } \\
\hline & & \multicolumn{2}{|c|}{ Separate Groups } & \multicolumn{2}{|c|}{ Combined Groups } \\
\hline & & Normal & Abnormal & Normal & Abnormal \\
\hline $\begin{array}{l}\text { Blood peak activity normal }>1 \cdot 7 \% / 1 \\
\text { Blood peak activity normal total }<8 \%\end{array}$ & $\begin{array}{l}\text { Normal } \\
\text { Abnormal } \\
\text { Normal } \\
\text { Abnormal }\end{array}$ & $\begin{array}{c}(33)^{1} \\
94 \% \\
6 \% \\
97 \% \\
3 \%\end{array}$ & $\begin{array}{l}(36) \\
42 \% \\
58 \% \\
36 \% \\
64 \%\end{array}$ & $\begin{array}{l}3 \% \\
1 \%\end{array}$ & $\begin{array}{l}22 \% \\
19 \%\end{array}$ \\
\hline Combined faecal and blood activities & $\begin{array}{l}\text { Both normal } \\
\text { Faeces abnormal, blood normal } \\
\text { Faeces normal, blood normal } \\
\text { Both abnormal }\end{array}$ & $\begin{array}{l}\text { (33) } \\
94 \% \\
3 \% \\
3 \%\end{array}$ & $\begin{array}{l}(36) \\
39 \% \\
6 \% \\
6 \% \\
50 \%\end{array}$ & $\begin{array}{l}1 \% \\
1 \%\end{array}$ & $\begin{array}{r}20 \% \\
6 \%\end{array}$ \\
\hline
\end{tabular}

${ }^{1}$ Figures in brackets indicate number of patients.

was $15 \%$ (S.D. $\pm 6 \%$ ). Taking a lower limit of normal of $1.7 \%$ per litre, two patients $(6 \%)$ with normal fat balances had abnormally low peak values and 15 patients $(42 \%)$ with steatorrhoea gave blood peak values in the normal range. Thus, an overall $25 \%$ of the patients showed discordance between fat balance results and peak blood radioactivity (Table V). The patients with concordant results showed qualitative rather than quantitative correlation, peak values ranging from 1.9 to $5.8 \%$ in the 'normal' group and from 0.3 to $1.7 \%$ in patients with faecal fat losses of 10 to $70 \%$. Using values for blood total radioactivity (corrected for total blood volume), and a lower limit of normal of $8 \%$ of intake, as suggested by Ruffin et al. (1956), $80 \%$ of the patients showed results corresponding with their faecal fat loss.

Faecal losses and blood peaks of radioactivity showed good negative correlation. Using the limits for normal faecal loss of less than $5 \%$ and peak 
blood values of more than $1.7 \%$, three patients $(4 \%)$ with normal faecal radioactivity showed abnormally low blood peaks and two patients $(3 \%$ ) had normal blood peaks with abnormal faecal losses. Blood and faecal results, therefore, corresponded in $93 \%$ of the patients. When combined faecal excretion and blood peak values were compared with fat balance results, both faecal and blood levels were normal in $37 \%$ of the 36 patients with steatorrhoea and one or other was normal in a further $11 \%$. All except one patient without steatorrhoea showed normal values (Table V).

VITAMIN A TOLERANCE TEST The lower limit of normal was taken as 80 i.u. $/ 100 \mathrm{ml}$. serum. Following an oral load, the mean normal rise was 1,770 i.u. $/ 100 \mathrm{ml}$. (S.D. \pm 595 i.u.). A normal response to a vitamin A load was assumed to be greater than 580 i.u.

Fasting levels of vitamin A bore no relationship to fat balance results. Thus, three well-nourished

TABLE VI

COMPARISON OF RESULTS OF FAT BALANCES AND LABELLED FAT AND VITAMIN A ABSORPTION

Fat Balances

\begin{tabular}{lll}
\hline Separate Groups & & Combined Groups \\
Normal Abnormal & Normal Abnormal
\end{tabular}

\begin{tabular}{lllll}
\hline & $(31)$ & $(32)$ & & (63) \\
Both normal & $65 \%$ & $13 \%$ & & $6 \%$ \\
A abnormal and I normal & $29 \%$ & $3 \%$ & & \\
& $32 \%$ & $31 \%$ & $16 \%$ & $16 \%$ \\
I abnormal and A normal & $3 \%$ & $28 \%$ & & \\
Both abnormal & $3 \%$ & $56 \%$ & $2 \%$ & \\
Figures in brackets indicate number of patients. & & \\
I normal $>1.7 \% 1 . ;$ A normal $>580$ i.u. $/ 100 \mathrm{ml}$.
\end{tabular}

normal controls had abnormally low fasting levels, as did half the patients with anaemia. Just over half $(55 \%)$ of the patients with steatorrhoea had normal fasting levels (Table VI). Reproducibility of the tolerance test results was excellent, with clear separation of normal from abnormal values.

In a quarter of the 87 patients examined, the rise in vitamin A levels did not correspond with the status of fat absorption (Table VI). Thirteen (29\%) of the patients with normal fat balances gave abnormal vitamin A results, while eight $(19 \%)$ of the patients with steatorrhoea showed a normal vitamin A peak. Patients with anaemia or endocrine disorders often showed abnormal vitamin A peaks despite normal fat absorption, while normal results in patients with steatorrhoea were found, especially after gastrectomy and in Crohn's disease. These patients did not differ clinically from patients with markedly abnormal vitamin A peak values.

No relationship was demonstrable between the fasting levels of vitamin $\mathrm{A}$ and subsequent tolerance test results.

Comparing peak blood radioactivity with vitamin A peaks in patients with normal fat balances showed abnormal results for both in one patient and abnormal results for one of these tests in a further $10(32 \%)$, nine of whom had an abnormal response to a vitamin A load. Four patients (13\%) with steatorrhoea had normal results for both tests while a further 10 patients $(31 \%)$ showed abnormal results for one test only, of whom nine had normal blood levels of radioactivity (Table VI).

SERUM CAROTENE The mean normal value for serum carotene was $88 \mu \mathrm{g}$. (S.D. $\pm 15 \mu \mathrm{g}$.). A serum carotene level of less than $58 \mu \mathrm{g}$. was considered abnormal. One-third of the 87 patients failed to show a reciprocal relationship between serum carotene and fat excretion. Thirty-six per cent of 45 patients with normal fat balances had abnormally low fasting carotene levels and $26 \%$ of 42 patients with steatorrhoea had normal fasting levels (Table VII). Carotene levels bore no relationship to fasting vitamin A levels, nor to the results of vitamin A tolerance tests (Table VIII).

TABLE VII

COMPARISON OF RESULTS OF FAT BALANCES, SERUM CAROTENE, AND VITAMIN A LEVELS

Fat Balance Results

\begin{tabular}{|c|c|c|c|c|c|}
\hline & & \\
\hline & & \multicolumn{2}{|l|}{ Separate } & \multicolumn{2}{|l|}{ Overall } \\
\hline & & Normal & Abnormal & Normal & Abnormal \\
\hline $\begin{array}{l}\text { Vitamin A } \\
\text { Vitamin A rise } \\
\text { Serum carotene }\end{array}$ & $\begin{array}{l}\text { Normal (>80 i.u.) } \\
\text { Abnormal } \\
\text { Normal (> } 580 \text { i.u.) } \\
\text { Abnormal } \\
\text { Normal (> } 58 \mu \text { g.) } \\
\text { Abnormal }\end{array}$ & $\begin{array}{l}\mathbf{4 5}) \\
69 \% \\
31 \% \\
71 \% \\
29 \% \\
64 \% \\
36 \%\end{array}$ & $\begin{array}{l}(42) \\
55 \% \\
45 \% \\
19 \% \\
81 \% \\
26 \% \\
74 \%\end{array}$ & $\begin{array}{l}16 \% \\
15 \% \\
18 \%\end{array}$ & $\begin{array}{r}26 \% \\
9 \% \\
13 \%\end{array}$ \\
\hline
\end{tabular}

Figures in brackets indicate number of patients. 
TABLE VIII

COMPARISON OF FAT BALANCE, SERUM CAROTENE, AND VITAMIN A RESULTS

\begin{tabular}{|c|c|c|c|c|c|c|}
\hline & & \multicolumn{5}{|c|}{ Fat Balance Results } \\
\hline & & \multicolumn{2}{|l|}{ Separate } & \multicolumn{3}{|l|}{ Overall } \\
\hline & & Normal & Abnormal & Normal & & Abnormal \\
\hline Vitamin A fasting and carotene & $\begin{array}{l}\text { Both normal } \\
\text { Normal and abnormal } \\
\text { Both abnormal }\end{array}$ & $\begin{array}{l}(45) \\
56 \% \\
22 \% \\
22 \%\end{array}$ & $\begin{array}{l}(42) \\
17 \% \\
50 \% \\
33 \%\end{array}$ & $\overline{11} \%$ & $\begin{array}{l}(87) \\
36 \%\end{array}$ & $8 \%$ \\
\hline Vitamin $\mathbf{A}$ rise and carotene & $\begin{array}{l}\text { Both normal } \\
\text { Normal and abnormal } \\
\text { Both abnormal }\end{array}$ & $\begin{array}{l}49 \% \\
38 \% \\
13 \%\end{array}$ & $\begin{array}{l}14 \% \\
19 \% \\
67 \%\end{array}$ & $\overline{7} \%$ & $29 \% 1$ & $7 \%$ \\
\hline
\end{tabular}

Normal fasting levels of vitamin A=above 80 i.u. $/ 100 \mathrm{ml}$. Normal rise=above 580 i.u. Normal level of serum carotene=above $58 \mu \mathrm{g} . / 100 \mathrm{ml}$. ${ }^{1}$ These figures indicate $22 \%, 7 \%, 15 \%$ respectively of patients with abnormal serum carotene levels and normal vitamin $A$ rise.

TABLE IX

CORRELATION OF FAT BALANCE RESULTS AND WATER LOAD EXCRETION

\begin{tabular}{|c|c|c|c|c|c|}
\hline & & \multicolumn{4}{|c|}{ Fat Balances } \\
\hline & & \multicolumn{2}{|c|}{ Separate Groups } & \multicolumn{2}{|c|}{ Combined Groups } \\
\hline & & Normal & Abnormal & Normal & Abnormal \\
\hline \multirow{3}{*}{ Water load ( $\%$ excreted) } & & (53) & (42) & \multicolumn{2}{|c|}{ (95) } \\
\hline & All results normal & $15 \%$ & $12 \%$ & & \multirow{2}{*}{$\begin{array}{l}5 \% \\
(20 \%)^{1}\end{array}$} \\
\hline & $\begin{array}{l}\text { Results normal or abnormal } \\
\text { All results abnormal }\end{array}$ & $\begin{array}{l}42 \% \\
43 \%\end{array}$ & $\begin{array}{l}33 \% \\
55 \%\end{array}$ & $\begin{array}{c}24 \% \\
(47 \%)\end{array}$ & \\
\hline
\end{tabular}

'The percentages in brackets indicate the 'worst possible' results, assuming that only one estimation had been carried out in any one patient of the middle group who had shown variable results.

The figures in brackets indicate numbers of patients in each group.

Comparing a combination of carotene and vitamin A tolerance test results with fat balances produced rather worse correlation than that given by the vitamin $A$ values alone. Six (13\%) patients with

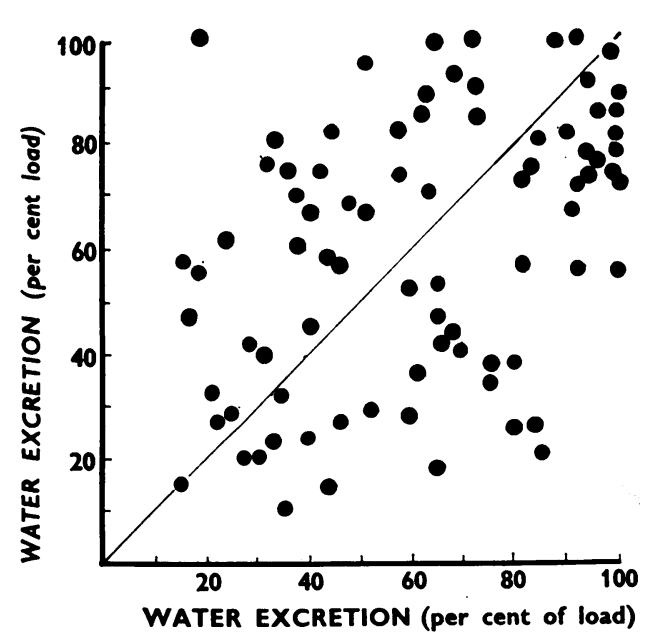

FIG. 1. Results of duplicate water load excretion. normal fat excretion gave doubly abnormal results, while both results were normal in six $(14 \%)$ of the patients with secondary steatorrhoea (Table VIII).

WATER LOAD EXCRETION EXcretion of more than $80 \%$ of a water load in five hours was considered normal.

Reproducibility of the diuretic response was totally unsatisfactory (Fig. 1). Furthermore, ability to excrete a water load bore no obvious relationship to the presence or degree of steatorrhoea (Table IX). Eighty-five per cent (45) of the patients with a normal faecal fat content showed impaired water load excretion on at least one occasion and $23(43 \%)$ of these gave consistently abnormal results. Five $(12 \%)$ of the patients with steatorrhoea had repeatedly a normal diuresis and a further $14(33 \%)$ excreted a water load normally on at least one occasion. Varying the water loads from 500 to $2,500 \mathrm{ml}$. did not change these results.

D-XYLOSE TOLERANCE TESTS Xylose excretion was fairly constant for each individual and did not change with alterations in fluid intake ranging from 500 to $2,500 \mathrm{ml}$. (Fig. 2). The mean normal five-hour 
TABLE X

COMPARISON OF FAT BALANCE RESULTS AND XYLOSE EXCRETION

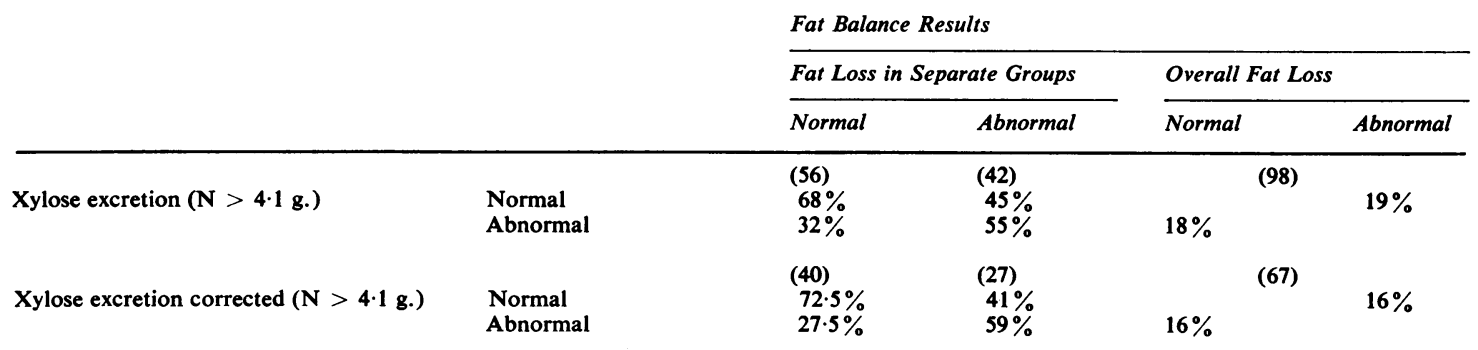

Figures in brackets indicate numbers of patients.

TABLE XI

COMPARISON OF RESULTS OF EXCRETION OF WATER LOAD AND OF XYLOSE

Fat Balance Results

\begin{tabular}{|c|c|c|c|c|c|}
\hline & & & & & \\
\hline & & Normal & & Abnorma & \\
\hline & & Xylose Ex & & & \\
\hline & & Normal & Abnormal & Normal & Abnormal \\
\hline Water load (normal > $80 \%$ ) & $\begin{array}{l}\text { Normal } \\
\text { Abnormal }\end{array}$ & $\begin{array}{c}(>4.1 \text { g.) } \\
16 / 35\end{array}$ & $2 / 17$ & $12 / 19$ & $5 / 23$ \\
\hline
\end{tabular}

Figures in this table indicate number of patients.

excretion was 5.9 g. (S.D. \pm 0.9 g.). The lower limit of normal was taken as $4.1 \mathrm{~g}$. in five hours.

The results of fat balances and xylose excretion were discordant in $37 \%$ of the 98 patients examined (Table X). Nineteen ( $32 \%$ ) of the patients with normal fat balance results showed abnormal xylose excretion. These patients, who were all less than

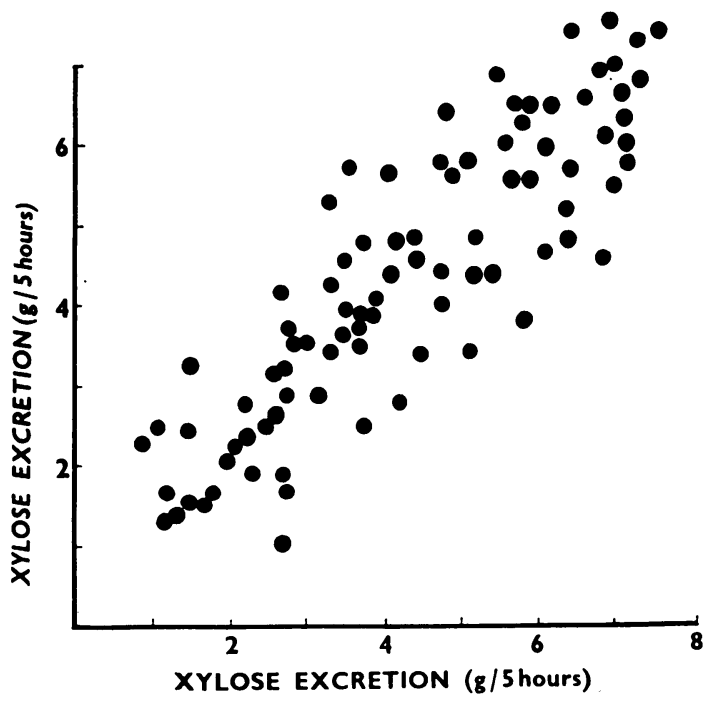

FIG. 2. Results of $d$-xylose tolerance tests.
55 years old, were anaemic or had hypofunction of the pituitary, thyroid, or adrenal glands. All the 19 patients $(45 \%)$ with steatorrhoea who excreted xylose normally had a secondary malabsorption state. Sixteen other patients $(24 \%)$ with secondary steatorrhoea gave values for xylose excretion in the intermediate range of 3 to $4 \mathrm{~g}$. in five hours. Using a xylose-creatinine ratio of xylose $0.25 \mathrm{~g}$. creatinine $/ 5 \mathrm{hr}$. urine it was possible to improve the definition of normal and abnormal results over this range. Fourteen of the 16 corrected results showed values less than $3 \mathrm{~g}$. or over $4.1 \mathrm{~g}$. Two values not previously in this range showed intermediate values after correction.

No correlation could be demonstrated between xylose excretion and diuretic response (Table XI). Twenty-eight $(52 \%)$ of 54 patients with xylose excretion greater than $4.1 \mathrm{~g}$. showed abnormal water load excretion and seven $(18 \%)$ of 40 patients with abnormal xylose excretion had a normal diuresis.

Comparison of the results of the xylose excretion test with those of the vitamin A tolerance test and peak blood radioactivity showed that in both instances two-thirds of the patients gave parallel results.

Comparison of xylose excretion with vitamin A rise indicated that $28(31 \%)$ of 89 patients gave normal values and $28(31 \%)$ abnormal values for both tests. Only $25(52 \%)$ of the patients with normal 
TABLE XII

COMPARISON OF RESULTS OF XYLOSE EXCRETION AND VITAMIN A TOLERANCE TESTS

\begin{tabular}{|c|c|c|c|c|c|}
\hline & & \multicolumn{4}{|c|}{ Xylose Excretion in 89 Patients } \\
\hline & & \multicolumn{2}{|l|}{ Normal } & \multicolumn{2}{|c|}{ Abnormal } \\
\hline \multirow[t]{5}{*}{ Vitamin $A$ increase (normal $>580$ i.u.) } & $\begin{array}{l}\text { Normal } \\
\text { Abnormal }\end{array}$ & $\begin{array}{l}31 \% \\
19 \%\end{array}$ & & $\begin{array}{l}19 \% \\
31 \%\end{array}$ & \\
\hline & & \multicolumn{4}{|c|}{ Fat Balances } \\
\hline & & \multicolumn{2}{|c|}{ Normal in 48 Patients } & \multicolumn{2}{|c|}{ Abnormal in 41 Patients } \\
\hline & & \multicolumn{4}{|c|}{ Xylose Excretion } \\
\hline & & Normal & Abnormal & Normal & Abnormal \\
\hline Vitamin $\mathbf{A}$ increase & $\begin{array}{l}\text { Normal } \\
\text { Abnormal }\end{array}$ & $52 \%$ & $\begin{array}{l}19 \% \\
21 \%\end{array}$ & $32 \%$ & $17 \%$ \\
\hline
\end{tabular}

TABLE XIII

COMPARISON OF XYLOSE EXCRETION AND PEAK RADIOACTIVITY

Xylose Excretion in 66 Patients

Normal $(>4 \cdot 1 \mathrm{~g}$.$) \quad Abnormal$

Peak radioactivity (normal $>1.7 \% / 1$.

Normal
Abnormal

$44 \%$

$23 \%$

$\begin{array}{rr}\text { Abnormal } & 11 \% \\ & \text { Fat Balances }\end{array}$

\begin{tabular}{|c|c|c|c|}
\hline Normal & ents & Abnorm & Patients \\
\hline Xylose E & & & \\
\hline Nermal & Abnormal & Normal & Abnormal \\
\hline $\begin{array}{l}67 \% \\
-\end{array}$ & $\begin{array}{r}30 \% \\
3 \%\end{array}$ & $\begin{array}{l}25 \% \\
19 \%\end{array}$ & $\begin{array}{l}17 \% \\
39 \%\end{array}$ \\
\hline
\end{tabular}

fat balances had normal results for both tests and only $18(44 \%)$ of the patients with steatorrhoea showed abnormal values for both (Table XII). Comparison of xylose excretion and peak radioactivity indicated that $29(44 \%)$ of 66 patients had normal results for both tests and $14(22 \%)$ gave abnormal results for both. Where fat balances were normal, $20(67 \%)$ showed normal results for both tests, all except one of the 'falsely abnormal' results being due to abnormal xylose excretion. Only $14(39 \%)$ of 36 patients with steatorrhoea gave doubly abnormal results, the 'falsely normal' values being evenly divided between the two tests (Table XIII).

\section{DISCUSSION}

The results obtained by the use of individual tests in this study agree well with the reports of other investigators (Tables XIV to XVIII). It is not proposed to discuss the individual procedures in detail but rather to indicate the conclusions to be drawn from an overall appraisal of the results.

Both the 'balance test' procedures (fat balance and ${ }^{131}$ iodine-labelled triolein excretion) show the
TABLE XIV

DAILY FAT EXCRETION IN HEALTHY NORMAL ADULTS

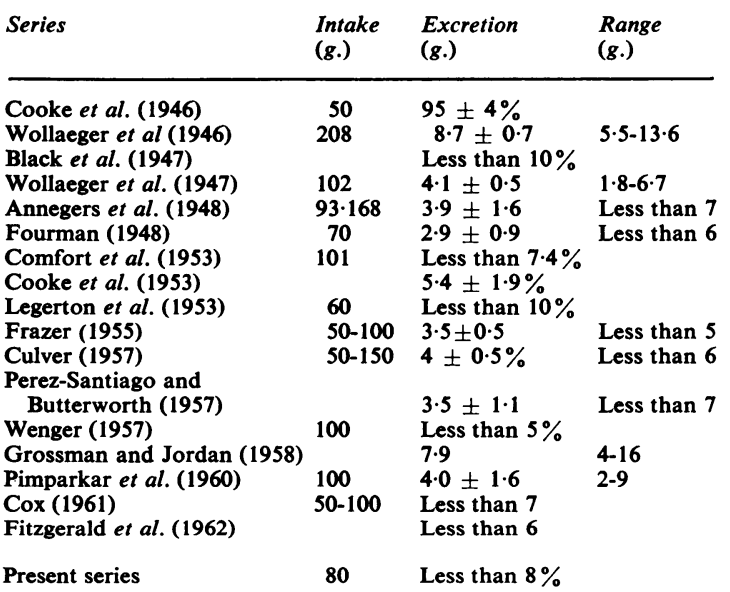

presence rather than the type of small intestinal dysfunction. The chemical estimation of faecal fat occasionally fails to detect the presence of severe small intestinal damage, since patients with total 
TABLE XV

NORMAL FAECAL EXCRETION AND BLOOD LEVELS AFTER ADMINISTRATION OF LABELLED FAT

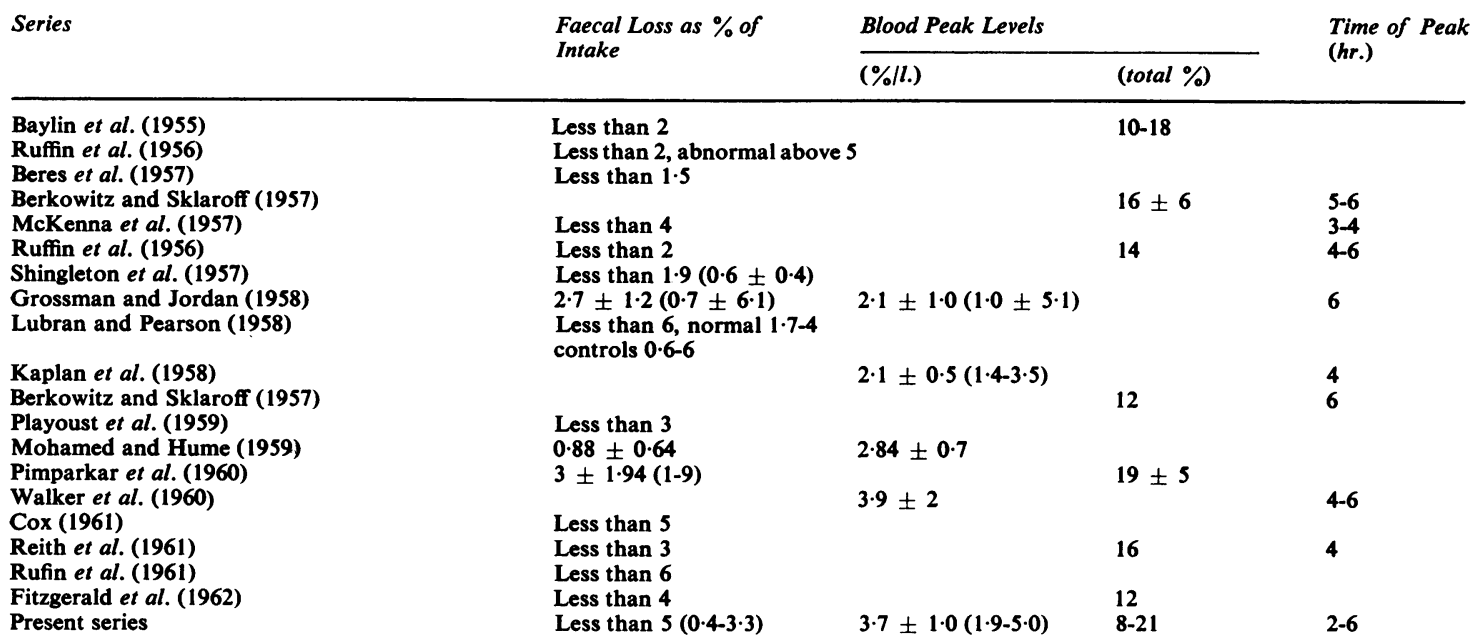

TABLE XVI

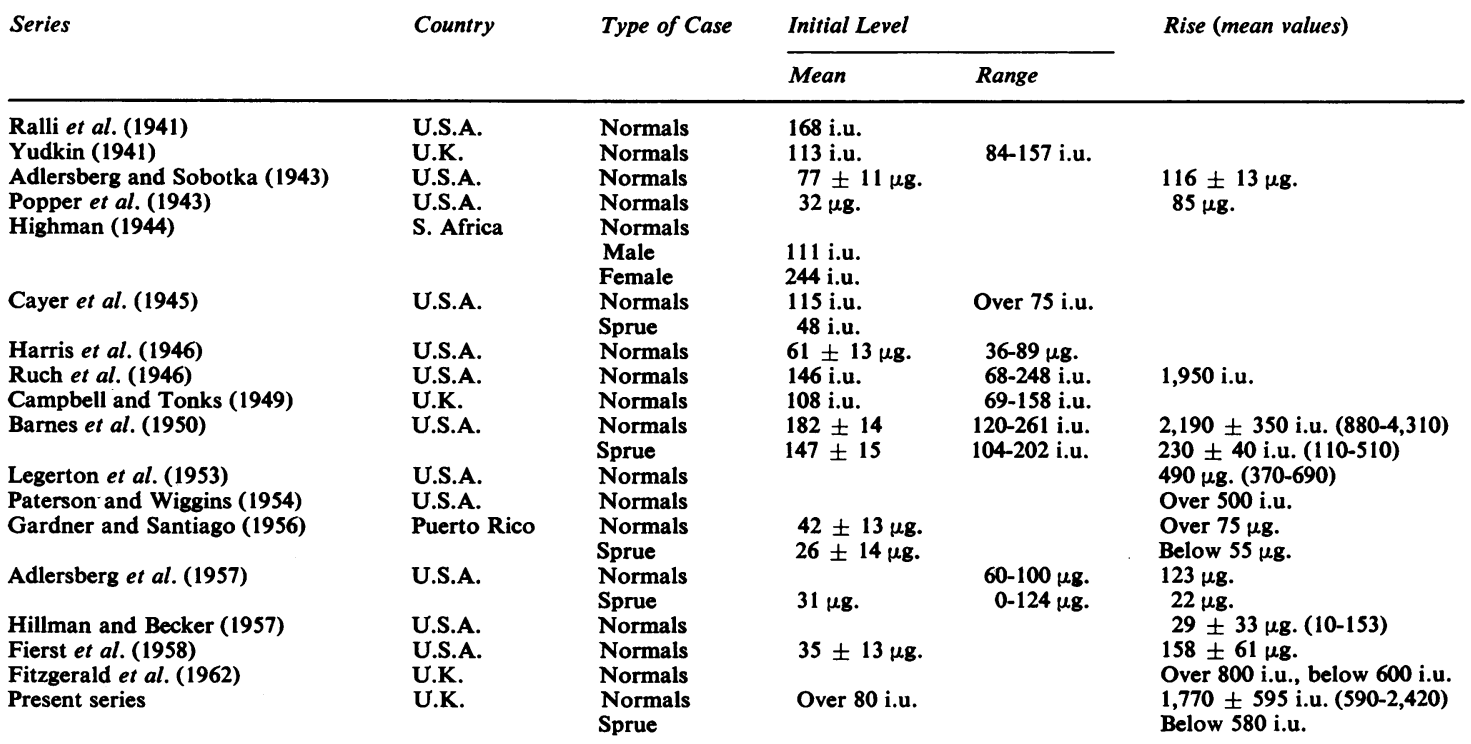

Conversion factors: $\mu \mathrm{g}$. to i.u. Harris et al. (1946) $\times 3.5$

Kimble technique $\times 2.5$

villous atrophy (not included in this series) have been found to have normal fat balances. This study confirms the impression that chemical estimation of faecal fat often shows steatorrhoea while faecal excretion of radioactivity remains normal (Pimparkar et al., 1960; Rufin et al., 1961; Cox, 1961). The proportion of false negative results as well as false positive values, such as were obtained by Playoust, Wyatt, and Blackburn (1959) in patients after gastrectomy and with ulcerative colitis, depends on the assumed maximal normal faecal content of radioactivity. In this study the use of an upper limit of normal faecal loss of $5 \%$ of intake produces excellent inverse correlation with blood levels, but further emphasizes the problem of the significance of false negative results. Although Jimenez-Diaz, Linazasoro, Marina, and Romero (1960) suggest that this type of response indicates an endogenous 
TABLE XVII

SERUM CAROTENE LEVELS IN HEALTHY PERSONS AND IN PATIENTS WITH SPRUE

\begin{tabular}{|c|c|c|c|c|}
\hline Reference & Country & Type of Case & $\begin{array}{l}\text { Mean } \\
(\mu \mathrm{g} . / 100 \mathrm{ml} .)\end{array}$ & Range \\
\hline \multirow[t]{2}{*}{$\begin{array}{l}\text { Yudkin (1941) } \\
\text { Adlersberg and Sobotka (1943) } \\
\text { Highman (1944) }\end{array}$} & $\begin{array}{l}\text { U.K. } \\
\text { U.S.A. } \\
\text { S. Africa }\end{array}$ & $\begin{array}{l}\text { Normals } \\
\text { Normals } \\
\text { Normals }\end{array}$ & $\stackrel{123}{83} \pm 5$ & $50-241$ \\
\hline & & $\begin{array}{l}\text { European } \\
\text { Indian } \\
\text { Bantu }\end{array}$ & $\begin{array}{l}207 \\
162 \\
131\end{array}$ & $110-400$ \\
\hline Cayer et al. (1945) & U.S.A. & $\begin{array}{l}\text { Normals } \\
\text { Sprue }\end{array}$ & $\begin{array}{l}269 \text { (i.u.) } \\
49\end{array}$ & Over 165 \\
\hline $\begin{array}{l}\text { Harris et al. (1946) } \\
\text { Campbell and Tonks (1949) }\end{array}$ & $\begin{array}{l}\text { U.S.A. } \\
\text { U.K. }\end{array}$ & $\begin{array}{l}\text { Normals } \\
\text { Normals }\end{array}$ & $\begin{array}{l}210 \pm 31 \\
80\end{array}$ & $\begin{array}{l}80-370 \\
20-199\end{array}$ \\
\hline Barnes et al. (1950) & U.S.A. & $\begin{array}{l}\text { Normals } \\
\text { Sprue }\end{array}$ & 79 & $\begin{array}{c}32-204 \\
3-16\end{array}$ \\
\hline Gardner and Santiago (1956) & U.S.A. (Puerto Rico) & $\begin{array}{l}\text { Normals } \\
\text { Sprue }\end{array}$ & $\begin{aligned} 120 & \pm 57 \\
47 & \pm 53\end{aligned}$ & \\
\hline Adlersberg et al. (1957) & U.S.A. & $\begin{array}{l}\text { Normals } \\
\text { Sprue }\end{array}$ & $100-200$ & \\
\hline $\begin{array}{l}\text { Wenger (1957) } \\
\text { Wenger et al. (1957) } \\
\text { Bezman et al. (1959) } \\
\text { Christiansen et al. (1959) }\end{array}$ & $\begin{array}{l}\text { U.S.A. } \\
\text { U.S.A. } \\
\text { U.S.A. } \\
\text { U.S.A. }\end{array}$ & $\begin{array}{l}\text { Normals } \\
\text { Normals } \\
\text { Normals } \\
\text { Normans }\end{array}$ & $\begin{array}{l}123 \\
123 \\
125 \\
31\end{array}$ & $\begin{array}{l}70-300 \\
70-282 \\
55-192 \\
70-320\end{array}$ \\
\hline Present series & U.K. & $\begin{array}{l}\text { Sprue } \\
\text { Normals } \\
\text { Sprue }\end{array}$ & $\begin{array}{l}31 \\
88 \pm 15 \\
\text { Below } 58\end{array}$ & $26-108$ \\
\hline
\end{tabular}

origin for the excess faecal fat, differences in the metabolic fate of labelled triolein and mixed dietary fats may better account for the disparity. Moreover, many of these patients show borderline steatorrhoea ( 8 to $20 \%$ fat loss), and the pathogenesis, clinical significance, and prognosis of this type of steatorrhoea requires further study. The use of a lower limit for maximal normal faecal radioactivity produces a smaller proportion of false negative results, but gives rise to new problems, including excessive faecal radioactivity with normal fat excretion and abnormal faecal radioactivity with normal blood levels. Since these additional anomalies cannot be explained, and may actually be artefacts, use of the higher normal limit of radioactivity in the stools seems justified at the present time.

Of the three tolerance tests used ( ${ }^{131}$ iodinelabelled triolein, vitamin A, and D-xylose) only labelled triolein gave consistent results and conclusions compatible with results of the balance tests. The inverse relationship between faecal and blood radioactivity noted by Ruffin et al. (1956) was confirmed. The failure of correlation between faecal fat losses and circulating radioactivity noted by McKenna, Bourne, and Matzko (1957), Beres, Wenger, and Kirsner (1957), Grossman and Jordan (1958), Mohamed and Hume (1959), Pimparkar et al. (1960), and Rufin et al. (1961) was also noted in this study, and attributed to the mechanisms already held to be responsible for the falsely low faecal radioactivity in these patients. Analysis of the other tolerance tests shows that abnormal results are found in severe malabsorption, but a similar failure to produce a normal increase in blood levels of vitamin A or urinary excretion of xylose may be found in patients with apparently normal alimentary tracts. Furthermore, the dysfunction responsible for steatorrhoea is not always, by itself, sufficient to give rise to abnormal tolerance tests, since patients with secondary malabsorption states often show normal results in the presence of quite marked losses of faecal fat. While Legerton, Texter, and Ruffin (1953) found flat vitamin A curves in steatorrhoea, Culver (1957) and Hillman and Becker (1957) noted abnormal results in normal persons, similar to those found in patients with anaemia or endocrinopathies in this study. Abnormal xylose excretion had been noted in patients older than 65 years (Fowler and Cooke, 1960) and in patients with pernicious anaemia (Helmer and Fouts, 1937; Bezman, Kinnear, and Zamcheck, 1959), and Butterworth, Perez-Santiago, Martinez de Jesus and Santini (1959) noted abnormal xylose excretion in patients with pernicous anaemia but not in those with irondeficiency anaemia. The present study emphasizes the occurrence of these falsely abnormal results in patients with both types of anaemia and in some endocrine disorders. Abnormal xylose excretion could not be correlated with inability to excrete water loads, although xylose retention tended to occur in patients with known inability to regulate body fluid volumes. Normal xylose excretion in patients with secondary steatorrhoea has been previously reported (Benson, Culver, Ragland, Jones, Drummey, and Bougas, 1957; Christiansen, Kirsner, and Ablaza, 1959; Fowler and Cooke, 1960), and is confirmed, although in a greater proportion and wider range of patients. 
TABLE XVIII

FIVE-HOUR URINARY XYLOSE EXCRETION

\begin{tabular}{|c|c|c|c|c|}
\hline \multirow[t]{2}{*}{ Series } & \multirow[t]{2}{*}{ Type of Case } & \multicolumn{3}{|c|}{ Five-hour Urinary Xylose Excretion (g.) } \\
\hline & & Mean & S.D. & Range \\
\hline Helmer and Fouts (1937) & $\begin{array}{l}\text { Normals } \\
\text { Pernicious anaemia }\end{array}$ & $\begin{array}{l}4 \cdot 7 \\
4 \cdot 3\end{array}$ & & $\begin{array}{l}4 \cdot 3-5 \cdot 3 \\
1 \cdot 5-7 \cdot 8\end{array}$ \\
\hline Fourman (1948) & $\begin{array}{l}\text { Normals } \\
\text { Sprue }\end{array}$ & $\begin{array}{l}6.0 \\
2 \cdot 1\end{array}$ & & $\begin{array}{l}4 \cdot 3-6 \cdot 7 \\
1 \cdot 4-2 \cdot 3\end{array}$ \\
\hline Brien et al. (1952) & Normals & $6 \cdot 1$ & 0.7 & \\
\hline Gardner and Perez-Santiago (1956) & $\begin{array}{l}\text { Normals } \\
\text { Sprue }\end{array}$ & $\begin{array}{l}5.6 \\
1.5\end{array}$ & $\begin{array}{l}0.6 \\
0.9\end{array}$ & \\
\hline Benson et al. (1957) & $\begin{array}{l}\text { Normals } \\
\text { Sprue } \\
\text { Gastrectomy } \\
\text { Pancreatitis } \\
\text { Crohn's disease }\end{array}$ & $\begin{array}{l}6 \cdot 5 \\
1 \cdot 3\end{array}$ & $\begin{array}{l}1 \cdot 2 \\
0.7\end{array}$ & $\begin{array}{l}4 \cdot 1-8 \cdot 2 \\
0 \cdot 8-2 \cdot 6 \\
1 \cdot 7-8 \cdot 8 \\
6 \cdot 0-10 \cdot 0 \\
0 \cdot 9-5 \cdot 4\end{array}$ \\
\hline Culver (1957) & Normals & 6.5 & $1 \cdot 2$ & \\
\hline Kalser (1957) & Sprue & $\begin{array}{l}1 \cdot 3 \\
6 \cdot 5\end{array}$ & 0.7 & \\
\hline & $\begin{array}{l}\text { Normais } \\
\text { Abnormal }\end{array}$ & & & Below 4 \\
\hline Finlay and Wightman (1958) & $\begin{array}{l}\text { Normals } \\
\text { Sprue }\end{array}$ & $\begin{array}{l}8 \cdot 5 \\
0.5\end{array}$ & $\begin{array}{l}0.9 \\
0.5\end{array}$ & $\begin{array}{l}\text { Over } 6 \\
0.2-6.8\end{array}$ \\
\hline Bezman et al. (1959) & $\begin{array}{l}\text { Normals } \\
\text { Pernicious anaemia }\end{array}$ & 5.7 & & $\begin{array}{l}3 \cdot 7-7 \cdot 9 \\
0 \cdot 8-6 \cdot 1\end{array}$ \\
\hline Butterworth et al. (1959) & $\begin{array}{l}\text { Normals } \\
\text { Sprue }\end{array}$ & $\begin{array}{l}5 \cdot 7 \\
1 \cdot 4\end{array}$ & & $3 \cdot 3-9 \cdot 2$ \\
\hline Christiansen et al. (1959) & $\begin{array}{l}\text { Normals } \\
\text { Sprue } \\
\text { Crohn's disease } \\
\text { Ulcerative colitis } \\
\text { Biliary obstruction }\end{array}$ & $\begin{array}{l}6.8 \\
1.8 \\
4.6 \\
7.6 \\
9.0\end{array}$ & $\begin{array}{l}0.9 \\
0.6\end{array}$ & $\begin{array}{l}5 \cdot 6-8 \cdot 2 \\
0 \cdot 6-2 \cdot 4 \\
2 \cdot 2-8 \cdot 3 \\
6 \cdot 0-10 \cdot 7 \\
8 \cdot 5-9 \cdot 4\end{array}$ \\
\hline Fowler and Cooke (1960) & $\begin{array}{l}\text { Normals }<65 \\
\text { Normals }>65 \\
\text { Pernicious anaemia } \\
\text { Sprue } \\
\text { Crohn's disease } \\
\text { Pancreatitis } \\
\text { Gastrectomy } \\
\text { Ulcerative colitis }\end{array}$ & $\begin{array}{l}7 \cdot 2 \\
2.9 \\
4 \cdot 9 \\
2 \cdot 8 \\
6 \cdot 0 \\
6 \cdot 3 \\
6 \cdot 1 \\
6 \cdot 7\end{array}$ & $\begin{array}{l}0.3 \\
0.3 \\
\\
0.4 \\
0.5\end{array}$ & $\begin{array}{l}4 \cdot 8-11 \cdot 5 \\
1 \cdot 5-4 \cdot 1 \\
2 \cdot 8-6 \cdot 5 \\
0 \cdot 4-5 \cdot 3 \\
3 \cdot 6-9 \cdot 5 \\
4 \cdot 2-10 \cdot 7 \\
4 \cdot 3-10 \cdot 3 \\
4 \cdot 2-9 \cdot 4\end{array}$ \\
\hline Present series & $\begin{array}{l}\text { Normals } \\
\text { Anaemias } \\
\text { Sprue } \\
\text { Crohn's disease } \\
\text { Pancreatitis } \\
\text { Gastrectomy } \\
\text { Ulcerative colitis } \\
\text { Biliary obstruction }\end{array}$ & $\begin{array}{l}5.9 \\
3 \cdot 6 \\
2.5 \\
3.4 \\
4.9 \\
3.9 \\
6 \cdot 1 \\
5.0\end{array}$ & $\begin{array}{l}0.9 \\
2.1 \\
1.0 \\
1.5 \\
1.7 \\
1.4 \\
1.0 \\
1.7\end{array}$ & $\begin{array}{l}4 \cdot 1-7 \cdot 2 \\
1 \cdot 0-6 \cdot 1 \\
0 \cdot 9-3 \cdot 9 \\
1 \cdot 8-6 \cdot 5 \\
2 \cdot 5-7 \cdot 1 \\
1 \cdot 7-6 \cdot 2 \\
3 \cdot 1-7 \cdot 5 \\
2 \cdot 5-7 \cdot 2\end{array}$ \\
\hline
\end{tabular}

Correlation between the results of the tolerance tests has received previous comment. Beres et al. (1957) noted good correlation between labelled triolein and vitamin A results, as did Fierst, Feldman, Solomon, and Langsam (1958) and Fitzgerald, Fennelly, and Hingerty (1962). These reports are not confirmed by the present study, because too many patients with normal fat excretion and normal blood radioactivity show abnormal results after vitamin A loads, while a significant proportion of patients with steatorrhoea and flat vitamin A curves produce normal levels of blood radioactivity. A similar tendency to abnormal xylose excretion in patients with normal blood levels of radioactivity vitiates correlation between the results of these two tests. Although both vitamin A and xylose tolerance tests tend to give false values in similar types of patients, only about two-thirds give concordant results.

The occurrence of 'inappropriate' levels of serum carotene is noted by Adlersberg, Wang, and Bossak (1957) and Wenger (1957), and is emphasized here by the high proportion of patients with and without steatorrhoea who show normal and abnormal levels respectively.

The results reported here show that, while neither vitamin A absorption, xylose excretion, nor fasting carotene levels can be used as screening procedures for the detection of malabsorption states, these tests are often useful in differentiating malabsorption due to small intestinal dysfunction of the type found in idiopathic steatorrhoea from that due to anomalies of digestion or focal pathology of the small intestine.

All the patients with idiopathic steatorrhoea gave abnormal results with vitamin $\mathrm{A}$ and xylose and had 
abnormal serum carotene levels. It is of interest that a few of these patients with quantitatively mild steatorrhoea showed a normal capacity for absorption of labelled triolein. This type of pattern, with normal faecal and blood levels of radioactivity and abnormal response to vitamin $\mathrm{A}$ and xylose loads, was found only in patients with idiopathic steatorrhoea. Although some of the patients with secondary steatorrhoea show patterns indistinguishable from severe idiopathic steatorrhoea, the occurrence of normal carotene levels, vitamin A absorption, or xylose excretion in the presence of marked steatorrhoea always suggests a secondary malabsorption state.

I wish to acknowledge the help of Dr. A. P. Dick, with whose permission and encouragement this work was carried out. I would also like to thank Mr. S. Davison, Dr. I. M. Sharman and Mr. J. L. Haybittle for their cooperation and advice, and Dr. R. G. Ollerenshaw for providing the photographic figures. I am particularly grateful to Dr. H. T. Howat for his invaluable guidance and criticism.

\section{REFERENCES}

Adlersberg, D., and Sobotka, H. (1943). Fat and vitamin A absorption in sprue and jejuno-ileitis. Gastroenterology, 1, 357-365.

Wang, C. I., and Bossak, E. T. (1957). Disturbances in protein and lipid metabolism in malabsorption syndrome. $\mathrm{J}$. Mt Sinai Hosp., 24, 206-220.

Annegers, J. H., Boutwell, J. H., and Ivy, A. C. (1948). The effect of dietary fat on fecal fat excretion and subjective symptoms in man. Gastroenterology, 10, 486-495.

Barnes, B. C., Wollaeger, E. E., and Mason, H. L. (1950). The comparative absorption of vitamin $\mathbf{A}$ from a water-miscible and an oily preparation by normal human adults and patients with steatorrhea. J. clin. Invest., 29, 982-987.

Baylin, G. J., Sanders, A. P., Isley, J. K., Shingleton, W. W., Hymans, J. C., Johnston, D. H., and Ruffin, J. M. (1955). ${ }^{131}$ blood levels correlated with gastric emptying determined radiographically. 2. Fat test meal. Proc. Soc. exp. Biol. (N.Y), 89, 54-56.

Benson, J. A. Jr., Culver, P. J., Ragland, S., Jones, C. M., Drummey, G. D., and Bougas, E. (1957). The d-xylose absorption test in malabsorption syndromes. New Engl. J. Med., 256, 335-339.

Beres, P., Wenger, J., and Kirsner, J. B. (1957). The use of $\mathbf{I}^{181}$ triolein in the study of absorptive disorders in man. Gastroenterology, 32, 1-16.

Berkowitz, D., and Sklaroff, D. (1957). The use of radioactive fat in the study of absorption in various disease states. A.M.A. Arch. intern. Med., 100, 951-958.

Bezman, A., Kinnear, D. G., and Zamcheck, N. (1959). D-xylose and potassium iodide absorption and serum carotene in pernicious anemia. J. Lab. clin. Med., 53, 226-232.

Black, D. A. K., Bound, J. P., and Fourman, L. P. R. (1947). Fat absorption in tropical sprue. Ouart. J. Med., 16, 99-109.

Bonsnes, R. W., and Taussky, H. H. (1945). On the colorimetric determination of creatinine by the Jaffe reaction. J. biol. Chem., 158, 581-591.

Brien, F. S., Turner, D. A., Watson, E. M., and Geddes, J. H. (1952) A study of carbohydrate and fat absorption from the normal and diseased intestine in man. 1. The absorption and excretion of D-xylose. Gastroenterology, 20, 287-293.

Butterworth, C. E. Jr., Perez-Santiago, E., Martinez de Jesus, J., and Santini, R. (1959). Studies on the oral and parenteral administration of $\mathrm{d}(+)$ xylose. New Engl. J. Med., 261, 157-164.

Campbell, D. A., and Tonks, E. L. (1949). Vitamin A, total carotenoids, and thymol turbidity levels in plasma. Test in normal subjects residing in the Midlands during 1947. Brit. med.J., 2, 1499-1501.

Cayer, D., Ruffin, J. M., and Perlzweig, W. A. (1945). Vitamin levels in sprue. Amer. J. med. Sci., 210, 200-207.
Christiansen, P. A., Kirsner, J. B., and Ablaza, J. (1959). D-xylose and its use in the diagnosis of malabsorptive states. Amer. $J$. Med., 27, 443-453.

Comfort, M. W., Wollaeger, E. E., Taylor, A. B., and Power, M. H. (1953). Nontropical sprue: observations on absorption and metabolism. Gastroenterology, 23, 155-178.

Cooke, W. T., Elkes, J. J., Frazer, A. C., Parkes, J., Peeney, A. L. P., Sammons, H. G., and Thomas, G. (1946). Anomalies of intestinal absorption of fat. I. The determination and significance of faecal fat. Quart. J. Med., 15, 141-155.

-, Peeney, A. L. P., and Hawkins, C. F. (1953). Symptoms, signs, and diagnostic features of idiopathic steatorrhoea. Quart. $J$. Med., 22, 59-77.

Cox, A. G. (1961). Assessment of the radiotriolein test in steatorrhoea. Brit. med. J., 2, 933-938.

Crosby, W. H., and Kugler, H. W. (1957). Intraluminal biopsy of the small intestine. The intestinal biopsy capsule. Amer. J. dig. Dis., 2, 236-241

Culver, P. J. (1957). Survey of methods for study of intestinal absorption. Ibid., 2, 620-627.

Fierst, S. M., Feldman, S. M., Solomon, N., and Langsam, A. (1958). An evaluation of the isotopic iodotriolein method; its correlation with vitamin A absorption. Gastroenterology, 35, 381-384.

Finlay, J. M., and Wightman, K. J. R. (1958). The xylose-tolerance test as a measure of the intestinal absorption of carbohydrate in sprue. Ann. intern. Med. 49, 1332-1347.

Fitzgerald, O., Fennelly, J. J., and Hingerty, D. J. (1962). Serum studies in man after administration of vitamin $\mathbf{A}$ acetate and vitamin A alcohol. II. In subjects suffering from disturbances of absorption and digestion. Gut, 3, 74-79.

Fourman, L. P. R. (1948). The absorption of xylose in steatorrhoea. Clin. Sci., 6, 289-294.

Fowler, D., and Cooke, W. T. (1960). Diagnostic significance of the D-xylose excretion test. Gut, 1, 67-70.

Frazer, A. C. (1955). Steatorrhoea. Brit. med. J., 2, 805-809.

Gardner, F. H., and Santiago, E. P. (1956). Oral absorption tolerance tests in tropical sprue. Arch. intern. Med., 98, 467-474.

George, E. P., and Hennessy, W. B. (1961). Radiotriolein test in steatorrhoea. Brit. med. J., 2, 1650.

Grossman, M. I., and Jordan, P. H. Jr. (1958). The radio-iodinated triolein test for steatorrhea. Gastroenterology, 34, 892-900.

Harris, P. L., Hickman, K. C. D., Jensen, J. L., and Spies, T. D. (1946). Survey of the blood plasma levels of vitamin A, carotene, ascorbic acid, and tocopherols of persons in an area of endemic malnutrition. Amer. J. publ. Hlth, 36, 155-160.

Harrison, G. A. (1957). Estimation of total and split fat, using a Soxhlet apparatus. In Chemical Methods in Clinical Medicine, 4th ed., p. 528. Churchill, London.

Helmer, O. M., and Fouts, P. J. (1937). Gastro-intestinal studies. VII. The excretion of xylose in pernicious anemia. J. clin. Invest., 16, 343-349.

Highman, S. E. (1944). The normal plasma carotene and vitamin A levels in young adults-European, Indian and Bantu. S. Afr. J. med. Sci., 9, 69-73.

Hillman, R. W., and Becker, N. H. (1957). Absorption of ingested vitamin A. Gastroenterology, 32, 738-746.

Jimenez-Diaz, C., Linazasoro, J. M., Marina, C., and Romero, J. M. (1960). Studies on idiopathic steatorrhea with $\left(\left(^{131}\right)\right.$ labeled fat. Gastroenterologia (Basel), 93, 228-235.

Kalser, M. H. (1957). Tests of malassimilation useful in the differential diagnosis of the malabsorption syndromes. Med. Clin. $N$. Amer., 41, 1553-1563.

Kaplan, E., Edidin, B. D., Fruin, R. C., and Baker, L. A. (1958).

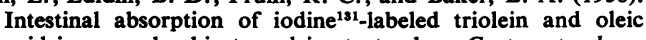
acid in normal subjects and in steatorrhea. Gastroenterology, 34, 901-909.

Legerton, C. W. Jr., Texter, E. C. Jr., and Ruffin, J. M. (1953). Observations on the vitamin $A$ tolerance curve as an index of the degree of fat absorption. Ibid., 23, 477-481.

Lubran, M., and Pearson, J. D. (1958). A screening test for steatorrhoea using ${ }^{181}$ I-labelled triolein. J. clin. Path., 11, 165-169.

Marshak, R. H., Wolf, B. S., and Adlersberg, D. (1954). Roentgen studies of the small intestine in sprue. Amer. J. Roentgen., 72, 380-400.

McKenna, R. D., Bourne, R. H., and Matzko, A. (1957). The use of $I^{181}$ labeled fat in the study of fat digestion and absorption in normal individuals and in patients with diseases of fat absorption. Gastroenterology, 32, 17-24. 
Mohamed, S. D., and Hume, R. (1959). Radioiodinated triolein in malabsorption states. J. clin. Path., 12, 535-540.

Paterson, J. C. S., and Wiggins, H. S. (1954). An estimation of plasma vitamin A and the vitamin A absorption test. Ibid.,7,56-60.

Perez-Santiago, E., and Butterworth, C. E. Jr. (1957). Definition and diagnosis of sprue. Amer. J. dig. Dis., 2, 225-235.

Pimparkar, B. D., Tulsky, E. G., Kalser, M. H., and Bockus, H. L. (1960). Correlation of radioactive and chemical faecal fat in different malabsorption syndromes. Brit. med .J., 2, 894-900.

Playoust, M. R., Wyatt, J. V., and Blackburn, C. R. (1959). Studies in fat absorption. III. The radiotriolein and radio-oleic acid absorption tests. Aust. Ann. Med., 8, 245-251.

Popper, H., Steigmann, F., and Zevin, S. (1943). On the variations of the plasma vitamin A level after the administration of large doses of vitamin A in liver disease. J. clin. Invest., 22, 775-783.

Ralli, E. P., Bauman, E., and Roberts, L. B. (1941). The plasma levels of vitamin A after the ingestion of standard doses: studies in normal subjects and patients with cirrhosis of the liver. $J$. clin. Invest., 20, 709-713.

Reith, W. S., Williams, E. S., and Thomas, M. J. (1961). The ${ }^{131}$ Itriolein fat-absorption test. Lancet, 2, 1229-1232.

Roe, J. H., and Rice, E. W. (1948). A photometric method for the determination of free pentoses in animal tissues. J. biol. Chem., 173, 507-512.

Ruch, D. M., Brunsting, L. A., and Osterberg, A. E. (1946). Use of vitamin A tolerance test in certain cases of dermatologic disorders. Proc. Mayo Clin., 21, 209-217.

Ruffin, J. M., Shingleton, W. W., Baylin, G. J., Hymans, J. C., Isley, J. K., Sanders, A. P., and Sohmer, M. F. Jr. (1956). $I^{131}$-labeled fat in the study of intestinal absorption. New Engl. J. Med., 255, 594-597.
Rufin, F., Bland, W. H., Nordyke, R. A., and Grossman, M. I. (1961). Reliability of $I^{131}$-triolein test in the detection of steatorrhea. Gastroenterology, 41, 220-224.

Shiner, M. (1959). Small intestinal biopsy: diagnostic and research value. Proc. roy. Soc. Med., 52, 10-14.

Shingleton, W. W., Baylin, G. J., Isley, J. K., Sanders, A. P., and Ruffin, J. M. (1957). The evaluation of pancreatic function by use of $I^{131}$ labeled fat. Gastroenterology, 32, 28-33.

Veall, N., and Vetter, H. (1952). An apparatus for the rapid estimation of tracer quantities of radioactive isotopes in excreta. Brit. J. Radiol., 25, 85-88.

Walker, W. F., Stewart, W. K., Morgan, H. G., and McKie, J. (1960). Clinical assessment of intestinal fat-absorption using radioactive fat. Brit. med. J., 1, 1403-1406.

Weijers, H. A., and van de Kamer, J. H. (1953). Coeliac disease. I. Criticism of the various methods of investigation. Acta paediat (Uppsala), 42, 24-33.

Wenger, J. (1957). Blood carotene and steatorrhea. Amer. J. dig. Dis., 2, 654-658.

—, Kirsner, J. B., and Palmer, W. L. (1957). Blood carotene in steatorrhea and malabsorptive syndromes. Amer. J. Med., 22, 373-380.

Wollaeger, E. E., Comfort, M. W., and Osterberg, A. E. (1947) Total solids, fat and nitrogen in the feces. III. A study of normal persons taking a test diet containing a moderate amount of fat. Gastroenterology, 9, 272-283.

- Weir, J. F. and Osterberg, A. E. (1946). Total solids, fat and nitrogen in the feces I. A. study of normal persons and patients with duodenal ulcer on a test diet containing large amounts of fat. Ibid., 6, 83-92.

Yudkin, S. (1941). Estimation of vitamin A and carotene in human blood. Biochem, J., 35, 551-556. 